\title{
doispontos:
}

\section{Habermas e o positivismo jurídico}

\author{
Delamar José Volpato Dutra ${ }^{1}$ [UFSC/CNPq] \\ djvdutra@yahoo.com.br \\ Professor do Departamento de Filosofia - UFSC \\ Pesquisador CNPq
}

\begin{abstract}
Resumo: uma das teses fundamentais de Habermas no que diz respeito à relação entre direito e moral é que o direito alivia três exigências que são feitas à moral, quais sejam, exigências cognitivas, motivacionais e organizacionais. Os defensores de uma relação forte entre direito e moral, como Dworkin, sustentam que a moral deve ser chamada para resolver os casos difíceis do direito. Ora, Habermas parece afirmar justamente o contrário, a saber, que é o direito que é chamado a suprir um déficit cognitivo da moral. $O$ texto explora as consequências dessa afirmação para a teoria discursiva do direito de Habermas, em relação a uma das teses fundamentais do positivismo jurídico, qual seja, a de que a moral não pode ser um fundamento para o direito justamente por causa de sua indeterminação cognitiva, razão pela qual os positivistas jurídicos afirmam o elemento de decisão última da autoridade do direito, sem que, para tal, o conteúdo seja o ponto determinante. O texto coteja o quanto a teoria discursiva do direito de Habermas se aproxima ou se afasta dessa tese fundamental do positivismo jurídico.
\end{abstract}

Palavras-chave: Habermas, teoria discursiva do direito, positivismo jurídico, filosofia do direito, moral

Abstract: one of Habermas' fundamental theses regarding the relationship between law and morals is that law relieves three demands that are made on morals, namely, cognitive, motivational and organizational demands. Proponents of a strong relationship between law and morality, such as Dworkin, argue that morality must be called upon to resolve hard cases of law. Habermas seems to affirm just the opposite, namely, that it is law that is called to fill a cognitive deficit in morals. The text explores the consequences of this statement for Habermas' discursive theory of law, in relation to one of the fundamental theses of legal positivism, namely, that morality cannot be a foundation for law precisely because of its cognitive indeterminacy, which is why legal positivists affirm the element of ultimate decision of the authority of law, without the content being the determining point. The text compares how much the Habermas discursive theory of law approaches or departs from this fundamental thesis of legal positivism.

Keyword: Habermas, discursive theory of law, legal positivism, philosophy of law, morals 


\section{Direito e moral: separação ou subordinação}

O positivismo jurídico pode ser caracterizado pela tese segundo a qual não há conexão necessária entre direito e moral ${ }^{2}$. A corrente contrária a esta é justamente a que defende uma conexão necessária entre o direito e a moral. Santo Tomás, por exemplo, não chega a dizer que a "lex iniusta non est lex", mas sim que "non lex sed legis corruptio" [não é lei, mas uma corruptela de lei]. Mesmo na aplicação do direito, ele afirma: "injustum judicium judicium non est"4 [um julgamento injusto não é um julgamento]. Na atualidade, Alexy defende a tese de que uma norma ou uma decisão jurídica moralmente errada seria defeituosa no sentido de não ser uma norma jurídica tout court ${ }^{5}$.

As críticas de Habermas ao positivismo jurídico são bastante evidentes em sua obra. Porém, para bem avaliar a relação entre a teoria discursiva do direito e o positivismo jurídico há que se ter presente a relação entre direito e moral por ele proposta. Se a tese da separação entre direito e moral puder ser considerada um dos elementos principais da definição do positivismo jurídico, não se poderá, então, obliterar o tratamento da mencionada relação, a qual está no cerne da obra de Habermas sobre o direito. De fato, já no prefácio de $\mathrm{FG}^{6}$, ele escreve que a relação complementar entre direito e moral não é mais entendida por ele, na obra em questão, do mesmo modo como o fizera nas Tanner Lectures ${ }^{7}$. Nesse sentido, ele imputa a Apel um acesso à problemática "por demais normativista", sugerindo, portanto, como sendo sua própria posição, uma ligação menos normativa do direito à moral ou, quiçá, uma ligação simplesmente funcional. A hipótese acalentada neste estudo é a de que Habermas inverte a mencionada relação. Se antes defendia que a moral complementava o direito, agora é este que passa a complementar aquela. Melhor dito, apesar de ele sustentar uma complementação recíproca ${ }^{9}$ entre direito e moral, a complementação jurídica da moral passa a ter franca vantagem sobre esta última, como ver-se-á.

As consequências de tal troca de posição determinarão boa parte dos esclarecimentos que o presente artigo pretende fazer. Deve-se ajuntar a essa proposição, ainda, a tese da neutralidade do princípio do discurso, tese que originará um princípio de justificação próprio para a moral e, também, um princípio próprio para o direito, sugerindo forte independência do direito com respeito à moral. Em relação, especificamente, ao papel da ética discursiva no empreendimento da filosofia do direito de Habermas, há quem sustente a sua supressão da arquitetônica de FG, interpretação que portaria conexão estrita com a tese da neutralidade moral do princípio do discurso. As duas teses, aqui mencionadas, da complementaridade e da neutralidade, concernem a determinações internas à própria teoria discursiva do direito na formulação que lhe confere Habermas, sendo, dessa forma, de particular importância para os objetivos pretendidos.

Ademais, sob um ponto de vista estrutural da obra habermasiana, o tratamento do positivismo jurídico pode ser mapeado do seguinte modo: 1] o positivismo jurídico é criticado de forma direta, a partir do exame, feito por Habermas, da regra de reconhecimento de $\operatorname{Hart}^{10}$. É neste ponto, portanto, que Habermas trata diretamente de Hart e parece criticá-lo de uma perspectiva dworkiniana, ou seja, a crítica se dá porque a regra de reconhecimento valida o que seria o direito apenas através da legalidade dos procedimentos legislativos, em detrimento da consideração pelo conteúdo ${ }^{11}$. Na resolução de casos difíceis, isso levaria ao decisionismo, pois o juiz faria seu julgamento discricionariamente. Entretanto, como se pretende mostrar, não só o apelo a conteúdos é problemático nos termos da teoria discursiva do direito, como, também, a especificação de tais conteúdos é deixada ao próprio direito operar, em razão da tese da indeterminação cognitiva da moral; 2] no próprio título de sua obra Faktizität und Geltung, a palavra Faktizität indica uma referência direta ao cerne do positivismo jurídico, em um sentido que será explicitado mais abaixo. Com relação à segunda palavra do título, ela remete, por seu turno, ao cerne de sua teoria discursiva do direito. Parece, assim, que ele tenta reconciliar o positivismo jurídico com a teoria discursiva do direito. $\mathrm{O}$

${ }^{11} \operatorname{TrFG} 1$ p.250 [FG p. 247]. 
ponto, contudo, pretende-se sustentar, é que tal reconciliação é feita com franca vantagem para as teses do positivismo jurídico. Vale observar, em acréscimo, que Habermas é um crítico ferrenho da teoria do direito natural, rival histórica do positivismo jurídico. Ainda que ele afirme, categoricamente, que "a nau da teoria do discurso navega entre os escolhos do direito natural e do positivismo do direito" ${ }^{12}$, é somente o direito natural que ele sustenta não estar mais disponível ${ }^{13}$. O que Habermas pretende é substituir o direito natural pela ética discursiva. Porém, sendo a ética discursiva de estirpe pós-metafísica, é de se perguntar se ela pode cumprir, ainda que de forma análoga, a função que antanho cumpria o direito natural, e como ela o faz.

A seguir, expor-se-á o positivismo jurídico, especialmente em sua versão exclusivista, a fim de, em seguida, comparar seus argumentos com certas consequências implicadas na teoria discursiva do direito de Habermas.

\section{Positivismo jurídico: a tese da separação entre direito e moral}

Raz, dentre outros ${ }^{14}$, destaca que um dos problemas centrais da Filosofia do direito é aquele da natureza do direito, ou seja, da busca por uma resposta à pergunta pelo que é o direito. Nesse sentido, ele aponta três teorias que tentam determinar o que é o direito: (1) a teoria linguística, em parte seguida por Hart, segundo a qual "all legal statements are statable by the use of sentences of the form 'Legally p"15; (2) a teoria da perspectiva do advogado, em parte seguida por Kelsen e Dworkin, para a qual "the law has to do with those considerations which it is appropriate for court to rely upon in justifying their decisions" ${ }^{16}$. Raz anota que teorias com esta perspectiva têm em vista o momento da deliberação, o que levaria à busca de uma justificação, finalizando por assumir uma conotação especificamente moral, pois a moral concerniria precisamente nas melhores justificações das normas e das ações; (3) a teoria institucional, como a de Austin, Bentham e do próprio Raz, nos termos da qual "law consists only of athoritative positivist considerations" ${ }^{\prime 17}$. Uma teoria assim concebida não teria conotação moral porque trataria da parte executiva do direito e não da parte deliberativa.

De acordo com essa estrutura conceitual, para se ter uma definição mais precisa do positivismo jurídico poder-se-ia recorrer a uma passagem da obra de Austin:

"The existence of law is one thing; its merit or demerit is another. Whether it be or not be is one enquiry; whether it be or be not conformable to an assumed standard, is a different enquiry. A law, which actually exists, is a law, though we happen to dislike it, or though it vary from the text, by which we regulate our approbation and disapprobation"18.

\footnotetext{
${ }^{12} \operatorname{TrFG} 2313-4$ [FG p. 670].
}

13 TrFG1 247 [FG p. 244].

14 Por exemplo ALEXY, Robert. The Nature of Legal Philosophy. Ratio Juris. V. 17, n. 2, 2004, p. 156-67; ALEXY, Robert. On Two Juxtapositions: Concept and Nature, Law and Philosophy. Some Comments on Joseph Raz's "Can There Be a Theory of Law?” Ratio Juris. V. 20, N. 2, 2007, p. 162-9. Para Kant, por outro lado, o que caracteriza a Filosofia do Direito é o estudo do direito sob o ponto de vista da justiça. Essa matriz própria da disciplina pode ser percebida já no início da Doutrina do direito. De fato, nos $₫ A, B$ e $C$ da Introdução a essa obra, Kant distingue lei [Gesetz] de direito [Recht]. Assim, ele pode diferenciar uma doutrina do direito positivo - ou seja, uma doutrina do direito cuja preocupação é a lei [Gesetz, ius] no sentido da lei positiva, - e uma doutrina do direito que tem por objeto o direito justo [Recht, iustum]. O especialista da primeira [iurisconsultus] seria o conhecedor do que "dizem ou disseram as leis [Gesetz] em um certo lugar e em um certo tempo" (quid sit iuris). O especialista da segunda seria o filósofo, visto que este buscaria o fundamento [Grundlage], ou seja, "o critério universal com que se pode conhecer em geral tanto o justo quanto o injusto (iustum et iniustum)". Para uma melhor discussão dessa temática ver VOLPATO DUTRA, Delamar José. Manual de Filosofia do Direito. Caxias do Sul: Educs, 2008, especialmente o capítulo 1.

15 RAZ, Joseph. Ethics in the Public Domain: Essays in the Morality of Law and Politics. Oxford: Clarendon, 1994, p. 198.

16 RAZ, Joseph. Ethics in the Public Domain: Essays in the Morality of Law and Politics. Oxford: Clarendon, 1994, p. 199.

17 RAZ, Joseph. Ethics in the Public Domain: Essays in the Morality of Law and Politics. Oxford: Clarendon, 1994, p. 206.

18 AUSTIN, John. The Province of Jurisprudence Determined. New York: Noonday, 1954. [1. ed. 1832], p. 157. 
Não obstante tal formulação, no mundo anglo-saxão, o positivismo jurídico se tornou caudatário da filosofia de Hart, cuja obra principal nasce como uma crítica ao direito natural, bem como a Austin e a Bentham. Um dos pontos-chave da teoria de Hart em relação àquela de Austin (e Bentham), especialmente baseada na coação, que concebia o direito como um comando, foi considerar o direito sob a perspectiva do participante. O ponto de vista interno ao direito, ou seja, aquele do participante, permite a Hart formular o direito com aproximações, às vezes indistintas em relação à moral, constituindo, certamente um aspecto do seu positivismo bastante diferente de outras formulações do mesmo.

Veja-se como isso se explica. Segundo ele, o direito é constituído de regras primárias dirigidas às pessoas em geral e de regras secundárias dirigidas às autoridades. As regras secundárias dizem como identificar, modificar e aplicar as regras primárias. A regra de reconhecimento, o conceito mais importante de Hart, é uma regra secundária dirigida às autoridades. A regra de reconhecimento é "a rule for conclusive identification of the primary rules of obligation"19. Nas palavras do comentador: "is a framework of normative presuppositions that underlie the law-identifying behavior of the officials in the system"20. Ela operará como tal mesmo se permanecer inarticulada, mais ou menos como a gramática da linguagem natural, - segundo a qual os falantes aderem a um conjunto de prescrições que determinam a sua fala, - é operante mesmo que os sujeitos não consigam explicitar as suas regras.

Com relação a essa temática, Dworkin argumentou que a regra de reconhecimento, por um lado, não poderia dar conta do status legal dos princípios que compõem a ordem jurídica. Por outro lado, caso a regra de reconhecimento fosse capaz de diferenciar princípios de regras e compreender o papel daqueles, ela não mais serviria àquilo que Hart afirmava servir, pois em razão do escopo indeterminado dos princípios, ela não poderia funcionar como um instrumento teórico de identificação do que seria o direito ${ }^{21}$. Hart, em seu Postscript ao The Concept of Law, publicado postumamente ${ }^{22}$, rejeitou tal acusação, adotando a interpretação inclusivista de sua própria $\mathrm{obra}^{23}$, interpretação esta que será explicitada abaixo.

Por um lado, nem Austin e nem Kelsen - os quais se posicionam contra a teoria concorrente do positivismo jurídico, a saber, a teoria do direito natural - são o foco principal dos debates contemporâneos em relação a essa corrente da filosofia do direito. Por outro lado, o debate atual é muito mais interno ao próprio positivismo jurídico do que em oposição às teorias concorrentes de Dworkin, de Habermas e do direito natural.

O mencionado debate interno ao positivismo ocorre entre os defensores do "inclusive legal positivism", nomeado pelo próprio Hart em seu Postscript de "soft legal positivism" ou "incorporationist", e os defensores do "exclusive legal positivism", também conhecido como "hard legal positivism". O pomo da discórdia entre os dois grupos está na interpretação de um ponto central do positivismo jurídico, justamente aquele da conexão entre direito e moral ${ }^{24}$. O primeiro grupo que inclui Raz, Marmor, Himma, Shapiro, dentre outros, defende que a moral não é um critério necessário, e muito menos suficiente, para dar cunho jurídico a uma norma. Para eles, os conteúdos do direito, bem como a sua existência, são completamente

19 HART, Herbert. L. A. The Concept of Law. Oxford: Oxford University Press, 1961, p. 92.

20 KRAMER, Matthew H. Where Law and Morality Meet. Oxford: Oxford University Press, 2004, p. 2. A regra de reconhecimento "is an array of norms on the basis of which the officials determine what counts as legally binding and what does not" [KRAMER, Matthew H. Where Law and Morality Meet. Oxford: Oxford University Press, 2004, p. 110].

21 DWORKIN, Ronald. Taking Rights Seriously. London: Duckworth, 1977.

22 O mencionado Postscript se encontra em HART, H. L. A. The Concept of Law. 2. ed., Oxford: Clarendon Press, 1994.

23 HART, H. L. A. The Concept of Law. 2. ed., Oxford: Clarendon Press, 1994, p. 250s.

24 Sobre essa temática ver VOLPATO DUTRA, Delamar José, LOIS, C. C. Modelos de moralização do direito: um estudo a partir de Habermas. Seqüência. V. 55, 2007, p. 233-252. 
determinados pela fonte social de onde o mesmo se origina. O segundo grupo, representado por autores como Coleman e pelo próprio Hart, defende que o direito pode portar uma conexão com a moral. Sobre esse ponto ainda voltar-se-á adiante.

Essa oposição entre os positivistas nasce, em grande parte, da reação da teoria positivista às críticas feitas por Dworkin em Taking Rights Seriously ${ }^{25}$, especialmente contra Hart. Ele teceu várias críticas ao positivismo, mas duas delas são particularmente interessantes para o presente contexto: A] o direito não é só composto de regras, mas também de princípios. Isso conferiria ao direito, segundo ele, um caráter essencialmente controverso, o que seria incompatível com a regra de reconhecimento de Hart; $B]$ a validade jurídica não é, por sua própria natureza, separada de considerações de conteúdo e mérito. Acima de tudo, não é separada de questões morais. Segundo Dworkin, pelas razões expostas, o positivismo jurídico não conseguiria dar conta, adequadamente, do papel que os princípios morais desempenhariam, principalmente na resolução dos casos difíceis.

Em textos posteriores, Dworkin explicitou melhor a sua concepção. Segundo ele, os atos do legislativo e do judiciário, tomados em seu conjunto, pressupõem uma moralidade política. Essa moralidade política compõe o direito. Ela opera, portanto, já na própria fonte de onde se origina o direito, de tal modo que a eficácia de uma lei como razão de agir passa a depender em grande medida do seu conteúdo. Por exemplo, as leis nazistas não mereceriam respeito porque flagrantemente imorais nos termos de uma moral do igual respeito e consideração, a começar pelo desrespeito fundamental pela vida de todos. De fato, Dworkin sustenta que a diferenciação empírica de instituições jurídicas, ou seja, a questão sociológica do que "makes a particular structure of governance a legal system rather than some other form of social control, such morality, religion, force, or terror" ${ }^{\text {"26 }}$ has "neither much practical nor much philosophical interest" se comparado à "doctrinal question" do que "makes a statement of what the law of some jurisdiction requires or permits true?"27. No final, a posição de Dworkin é a de que "we might treat law not as separate from but as a department of morality" ${ }^{\text {", }}$, isso é, "we might treat legal theory as a special part of political morality distinguished by a further refinement of institutional structures" 29 .

Como resposta a essa crítica de Dworkin, originou-se o positivismo jurídico inclusivo, o qual aceita que a moral possa ser parte das condições suficientes da validade do direito em um sistema jurídico determinado. Contudo, tratar-se-ia sempre de uma aceitação contingente, derivada de uma escolha originária da fonte do direito, e não decorrente da própria natureza deste. Assim, o positivismo jurídico inclusivo seria uma reação ${ }^{30}$ da teoria positivista que permitiria acomodar essas e outras críticas de Dworkin, sem abandonar o principal para a teoria, ou seja, o fundamento do direito em fatos sociais e convenções. Nessa perspectiva, o positivismo jurídico inclusivo poderia ser definido do seguinte modo: "it can be the case, though it needs not to be the case, that a norm's consistency with some or all of the requirements of morality is a precondition for the norm's status as a law in this or that jurisdiction" ${ }^{\text {31 }}$. Vale dizer, tal condição de validade não é inerente ao conceito de direito, mas pode ser imposta como um teste de validade em um regime jurídico determinado.

${ }^{25}$ Trata-se, na verdade, do cap. 2 do livro que é uma republicação de um artigo inicialmente editado em 1967: DWORKIN, Ronald. The Models of Rules. University of Chicago Law Review. N. 14, 1967.

${ }^{26}$ DWORKIN, Ronald. Hart and the Concepts of Law. Harvard Law Review Forum. V. 119, 2006, p. 95.

${ }^{27}$ DWORKIN, Ronald. Hart and the Concepts of Law. Harvard Law Review Forum. V. 119, 2006, p. 96.

${ }^{28}$ DWORKIN, Ronald. Justice in Robes. Cambridge: Harvard University Press, 2006, p. 34.

${ }^{29}$ DWORKIN, Ronald. Justice in Robes. Cambridge: Harvard University Press, 2006, p. 35.

${ }^{30}$ KRAMER, Matthew H. Where Law and Morality Meet. Oxford: Oxford University Press, 2004, p.2.

${ }^{31}$ KRAMER, Matthew H. Where Law and Morality Meet. Oxford: Oxford University Press, 2004, p. 2. 
Portanto, o positivismo jurídico inclusivo é inclusivo porque contempla princípios morais entre os critérios que guiam as autoridades na determinação do que é o direito, e ele é positivista porque rejeita o ponto de vista segundo o qual todo sistema jurídico tenha de ter, entre seus critérios de determinação, padrões morais ${ }^{32}$. Com efeito, pode ser o caso que um princípio moral seja um critério suficiente para a determinação do caráter jurídico de uma norma, mas essa não é uma condição necessária ínsita à própria definição de uma norma jurídica. Dessa forma, se concede a Dworkin que os princípios morais possam entrar na ordem jurídica, mas não que tenham de necessariamente fazer parte dela. Os inclusivistas são, portanto, acomodacionistas da moral no sistema jurídico. Porém, a acusação que é dirigida a eles é a de fazerem tantas concessões que os seus possíveis ganhos acabariam por se constituir em uma vitória de Pirro ${ }^{33}$. Hart, nesse sentido, como já mencionado, pode ser considerado um caso de positivismo jurídico inclusivo, algo por ele mesmo admitido no seu Postscript, sendo Coleman um de seus expoentes contemporâneos.

Por seu turno, o positivismo jurídico exclusivo "maintain that the very nature of Law is inconsistent both with the role of moral principles as legal norms and with their role as criteria for validating legal norms" ${ }^{\prime 3}$. Assim, quando a moral funciona como um standard que afeta uma decisão das autoridades é porque a mesma não foi tomada em bases exclusivamente legais, como deveria ser. Em outras palavras, "the operativeness of such principles in adjudication is not to be mistaken for their having become elements of the Law" ${ }^{35}$. Assim como o uso que o direito faz da aritmética não a transforma em um conceito jurídico, da mesma forma, o fato de o direito empregar conceitos morais não tem o condão de transformá-los em conceitos jurídicos, de tal forma que, sustentam os exclusivistas, direito e moral são essencialmente separados, e não só acidentalmente separados, como poderia ser inferido da posição inclusivista.

Para a posição exclusivista, haveria certas propriedades ínsitas ao direito que aqueles que tergiversam com a moral não dariam conta ${ }^{36}$, como, "its claim to authoritativeness, its capacity to guide behavior, its coventionality, its regularity, its institutional stratification capped by some Paramount tribunal (s)"37. Shapiro, por exemplo, sustenta que os inclusivistas não dão conta da "Law's essencial 'guidance function"'38. Isso ocorreria porque o positivismo jurídico inclusivo "allows the existence of a valid legal norm to depend on controversial moral questions that law's introduction was supposed to have eliminated" ${ }^{39}$. Com isso, a moral, e não o direito, passaria a ser a guia motivacional e epistemológica, porém, ela seria ineficaz nesse particular, pela razão que será apontada mais adiante. Raz, cuja teoria será apresentada abaixo, como um dos principais representantes da posição exclusivista, sustenta que a conexão necessária entre direito e

\footnotetext{
${ }^{32}$ KRAMER, Matthew H. Where Law and Morality Meet. Oxford: Oxford University Press, 2004, p. 2.

${ }^{33}$ Uma argumentação semelhante a essa pode ser encontrada em DWORKIN, Ronald. Justice in Robes. Cambridge: Harvard University Press, 2006.

${ }^{34}$ KRAMER, Matthew H. Where Law and Morality Meet. Oxford: Oxford University Press, 2004, p. 2.

${ }^{35}$ KRAMER, Matthew H. Where Law and Morality Meet. Oxford: Oxford University Press, 2004, p. 5.

36“[...] todo positivista exclusivo propõe um tipo de argumento a priori sobre o direito que tem sempre a mesma forma lógica: (1) há uma característica $\mathrm{C}$ que é indispensável para o conceito de direito; (2) critérios morais são imcompatíveis com a característica C; (3) logo, critérios morais são incompatíveis com o conceito de direito. [...] Em Raz a característica C é a reivindicação de autoridade, que implica a reinvindicação de razões excludentes e de preempção de razões, sem a qual o direito se ofereceria como facultativo, em vez de obrigatório. O motivo por que a reivindicação de autoridade é incompatível com critérios morais é que critérios morais só são vinculantes par quem concorde com eles racionalmente, abrindo-se para a crítica e questionamento do destinatário, o que constitui precisamente o inverso da reivindicação de autoridade sem a qual o direito deixa de ser direito" [COELHO, André. O positivismo exclusivo de Andrei Marmor: convenções e interpretação. In TORRANO, Bruno, OMMATI, José Emílio Medauer. O positivismo jurídico no século XXI. Rio de Janeiro: Lumen Juris, 2018, p. 273].
}

${ }^{37}$ KRAMER, Matthew H. Where Law and Morality Meet. Oxford: Oxford University Press, 2004, p. 9.

${ }^{38}$ SHAPIRO, Scott. Law, Morality, and the Guidance of Conduct. Legal Theory. V. 6, 2000, p. 127-170.

${ }^{30}$ WALUCHOW, W J. Legality, Morality, and the Guiding Function of Law. In KRAMER, Matthew H. et al (eds.). The Legacy of H. L. A. Hart. Oxford: Oxford University Press, 2008, p. 89. 
moral "it is insufficient e.g. to establish a prima-facie obligation to obey the Law" ${ }^{\text {". }}$. Ou seja, tal posição não daria conta da "authoritative nature of Law".

Em síntese, para os exclusivistas, trata-se da defesa da tese da separação entre moral e direito, a saber, que o critério para a validade jurídica de qualquer norma não pode incluir testes morais, e, juntamente com isso, a sustentação da 'sources thesis' como suficiente para determinar o que é o direito, em vez da tese do mérito da norma. A mencionada tese da origem pode ser assim formulada: "that the existence of legal norms must depend exclusively on whether they have the appropriate source in, e.g., precedent or parliamentary legislation" ${ }^{\prime \prime}$.

Da mesma maneira que Hart constrói a sua teoria como uma crítica aos teóricos do direito natural e a Bentham, Raz se opõe a Dworkin, que ele vê como um representante do direito natural, ainda que com um matiz próprio, e a Hart, como um representante do positivismo jurídico inclusivo. O problema que está em questão na filosofia do direito de Raz, "in particular it concerns the question whether it is ever the case that a rule is a rule of law because it is morally binding, and whether a rule can ever fail to be legally binding on the ground that it is morally unacceptable"42. Trata-se, portanto, da análise do vínculo entre moral e direito para saber se este vínculo é uma condição necessária e suficiente da validade de uma norma jurídica. Nesse particular, para Hart, como visto, o conteúdo e a existência de uma lei devem ser considerados como um fato social, cuja conexão com a moral é contingente e precária.

Raz sumariza três teses sobre a mencionada relação entre direito e moral, as quais permitem também classificar as várias teorias existentes sobre o assunto. Elas são: (a) a tese da origem ou da fonte (the sources thesis), segundo a qual todo o direito é baseado na fonte estabelecida de onde se origina; (b) a tese da incorporação, segundo a qual todo o direito é baseado na fonte estabelecida de onde se origina ou de algum modo tem um vínculo com tal base; (c) a tese da coerência, segundo a qual o direito é baseado na fonte estabelecida de onde se origina em conjunção com a sua melhor justificação moral ${ }^{43}$. Como se pode perceber nas duas últimas teses, o direito pode ser enriquecido por normas não originadas diretamente da fonte estabelecida de onde se originam as normas jurídicas, sendo que "the coherence thesis insists that every legal system necessarily includes such laws" ${ }^{\text {" }}$. A teoria de Dworkin pode ser classificada como coerentista segundo a análise anterior, assim como a de Hart pode ser considerada como pertencente à tese da incorporação. Raz, evidentemente, pretende seguir a primeira das teses.

O conceito fundamental no qual Raz baseia a sua teoria, como já mencionado, é aquele de autoridade. $\mathrm{O}$ interessante é que ele analisa tal conceito a partir de uma perspectiva inusitada, a saber, aquela da motivação para a ação. Assim, ele transforma a autoridade em uma razão para agir45, a qual pode, então, ser comparada com outras razões para agir, permitindo determinar, desse modo, as suas qualidades específicas em relação à moral, que é aquilo que lhe interessa. $\mathrm{O}$ que é distintivo das ordens emanadas da autoridade "is their special peremptory status" ${ }^{\text {", }}$ ou seja, a razão para agir originada da autoridade é terminativa, ela

${ }^{40} \mathrm{RAZ}$, Joseph. Ethics in the Public Domain. Oxford: Oxford University Press, 1994, p. 211; RAZ, Joseph. The Authority of Law. Oxford: Clarendon, 1979.

${ }^{41}$ WALUCHOW, W J. Legality, Morality, and the Guiding Function of Law. In KRAMER, Matthew H. et al (eds.). The Legacy of H. L. A. Hart. Oxford: Oxford University Press, 2008, p. 87.

${ }^{42}$ RAZ, Joseph. Ethics in the Public Domain: Essays in the Morality of Law and Politics. Oxford: Clarendon, 1994, p. 210.

${ }^{43}$ RAZ, Joseph. Ethics in the Public Domain: Essays in the Morality of Law and Politics. Oxford: Clarendon, 1994, p. 211.

${ }^{44}$ RAZ, Joseph. Ethics in the Public Domain: Essays in the Morality of Law and Politics. Oxford: Clarendon, 1994, p. 211.

${ }^{45}$ As ordens da autoridade "are reasons for actions for their subjects" [RAZ, Joseph. Ethics in the Public Domain: Essays in the Morality of Law and Politics. Oxford: Clarendon, 1994, p. 211].

46 RAZ, Joseph. Ethics in the Public Domain: Essays in the Morality of Law and Politics. Oxford: Clarendon, 1994, p. 212. 
tem que ser cumprida, não se podendo mais tergiversar sobre a mesma. Isso significa dizer que a decisão da autoridade tem que ser seguida pela simples razão de ter sido dita pela autoridade.

Segundo Raz, a ordem da autoridade que funciona como uma razão para agir pode ser considerada segundo um duplo aspecto. O primeiro seria aquele da dependência ou da conexão com outras razões, de tal forma que uma razão de agir é relacionada com outras razões de agir. É uma razão que vem colada com outras razões. Não obstante, tal caráter não pode ser entendido como se a ordem da autoridade contasse como uma razão entre outras. Não, ela resume um conjunto de razões na determinação da ação. O segundo aspecto é o de preempção. Como preempção, a ordem da autoridade é uma razão que substitui outras ${ }^{47}, \mathrm{e}$ não uma razão a mais dentre outras para agir. Ela é uma razão para agir que "replace the reasons on which it depends" ${ }^{48}$, de tal forma que ela irá determinar o que fazer.

Se o primeiro aspecto, aquele da dependência, que resume um conjunto de razões, fosse o único possível, então, a autoridade teria uma função de mediar as razões que as pessoas teriam para agir. Desse modo, um pai poderia tomar por justificada a pensão a que é condenado a pagar porque ele já acreditava que os pais devem sustentar os filhos. Entendida desse modo, as autoridades, segundo Raz, apenas refletiriam razões dependentes. Por isso, a autoridade precisa ser entendida de acordo com o segundo aspecto, como uma razão que substitui outras razões, a fim de marcar o propriamente peremptório de sua ordem. Como ver-se-á, é justamente esse segundo aspecto que parece faltar na perspectiva inclusivista, devido à sua contaminação por razões morais, obviamente alocadas na perspectiva da autoridade considerada sob o primeiro viés.

A autoridade, na formulação que lhe dá Raz, é tal que não pode ser mais questionada a partir das razões pelas quais ela surge e se determina ${ }^{49}$. Ou seja, as regras emanadas da autoridade visam a ofertar uma decisão final e obrigatória sobre matérias sujeitas inclusive a divergência moral. Para tal, é necessário que elas se baseiem não em um conteúdo moral, visto ele mesmo ser objeto de disputa, mas no simples fato da sua emissão pela autoridade competente. Como preempção, o direito nasceria como um Deus ex machina para resolver um conflito ${ }^{50}$. Portanto, a fonte da autoridade não pode residir em uma teoria moral, mas tem que operar como "pre-emptive reasons" ou como uma razão para a ação que exclui outras ${ }^{51}$. Em suma, "following this analysis, inclusive legal positivism must fail, it is argued, because it is inconsistent with a core aspect of law, the legal system's purporting to be a justified practical authority" ${ }^{\text {. }}$. Como mostrar-se-á abaixo, Hobbes e Schmitt já haviam chamado a atenção para aspectos muito semelhantes a estes.

Isso não significa que não se possa criticar uma tal razão de agir. $\mathrm{O}$ que fica excluída é uma ação que corresponda à crítica, de tal forma que "it is merely action for some of these reasons which is excluded"53. Ou seja, a reflexão sobre outras razões para agir pode continuar, mas não pode haver ação que se siga delas, se contrárias àquela determinada pela autoridade. Por exemplo, pode-se ter razões para não pagar o imposto de renda, como a corrupção, mas a ação de sonegar o tributo está excluída pela autoridade. In verbis, "the only proper way to acknowledge the arbitrator's authority is to take it to be a reason for

47 "I shall call a reason which displaces others a pre-emptive reason" [RAZ, Joseph. Ethics in the Public Domain: Essays in the Morality of Law and Politics. Oxford: Clarendon, 1994, p. 213].

${ }^{48} \mathrm{RAZ}$, Joseph. Ethics in the Public Domain: Essays in the Morality of Law and Politics. Oxford: Clarendon, 1994, p. 212.

${ }^{49}$ RAZ, Joseph. Ethics in the Public Domain: Essays in the Morality of Law and Politics. Oxford: Clarendon, 1994, p. 219.

${ }^{50} \mathrm{RAZ}$, Joseph. Ethics in the Public Domain: Essays in the Morality of Law and Politics. Oxford: Clarendon, 1994, p. 225.

${ }^{51}$ RAZ, Joseph. Ethics in the Public Domain: Essays in the Morality of Law and Politics. Oxford: Clarendon, 1994, p. 199s.

${ }^{52}$ BIX, Brian H. Legal Positivism. In GOLDING, Martin P., A. EDMUNDSON, William [Eds.]. The Blackwell Guide to the Philosophy of Law and Legal Theory. Oxford: Blackwell, 2006, p. 37.

${ }^{53}$ RAZ, Joseph. Ethics in the Public Domain: Essays in the Morality of Law and Politics. Oxford: Clarendon, 1994, p. 213. 
action which replaces the reasons on the basis of which he was meant to decide" ${ }^{54}$. A preempção não se mistura com outras razões, não sumariza outras razoes, mas as substitui. Nesse sentido, pode-se dizer que o legislativo cria razões para agir, substituindo quaisquer outras, e que o judiciário as aplica.

O passo seguinte de seu argumento é conectar autoridade e direito: "if the claim to authority is part of the nature of the Law, then whatever else the law is it must be capable of possessing authority"s5. Isso significa que mesmo uma lei ruim terá que ser obedecida. Portanto, se o direito tem autoridade, segue-se que ele tem todos os atributos não morais ou não normativos da autoridade ${ }^{56}$. Logo, a existência e o conteúdo de uma ordem da autoridade "cannot depend exclusively on the reasons for it. The existence and content of every directive depend on the existence of some condition which is itself independent of the reasons for that directive" ${ }^{57}$. Ou seja, ela tem que poder honrar o mencionado segundo aspecto da autoridade. Dessa forma, as fontes mais comuns do direito não obedecem a condições morais. Isso porque é um fato evidente que uma lei pode ser arbitrária e pode falhar em relação à sua aquiescência com as razões das quais dependeria. Da mesma forma, uma lei para ser compreendida e ser lei não precisa nem portar essa conexão com razões. Ela pode, simplesmente, ser uma lei só no segundo aspecto que foi declinado acima. Não precisa ter conexão alguma com outras razões, de tal forma que o aspecto mais importante é certamente o segundo que foi mencionado, a preempção.

Já Hobbes estabelecera a autoridade como contraponto à indeterminação do direito. Segundo ele, todas as leis precisam ser interpretadas, visto que dois fatores contribuem para gerar conflitos de interpretação: o primeiro é o da diversidade de significações das palavras; o segundo é o da cegueira que as paixões operam. Por mais verdadeiras que fossem as interpretações, sem a autoridade do Estado, elas não seriam leis, ou seja, mesmo com toda a evidência de verdade, uma interpretação não seria lei pela razão de ser verdadeira $^{58}$. A sentença, portanto, é uma interpretação que resolve um conflito de interpretações. Tal interpretação passa a ser lei, a ter força de lei, não pela sua verdade intrínseca, mas tão somente por ser dada pela autoridade do soberano ${ }^{59}$. A isso Heck chama de legalismo positivista absolutista ${ }^{60}$.

Schmitt tomará por base o capítulo XXVI do Leviathan, salientado no parágrafo anterior, para catalogar Hobbes como um representante do decisionismo, cuja conceituação remete à antítese entre auctoritas

${ }^{54} \mathrm{RAZ}$, Joseph. Ethics in the Public Domain: Essays in the Morality of Law and Politics. Oxford: Clarendon, 1994, p. 213.

${ }^{55}$ RAZ, Joseph. Ethics in the Public Domain: Essays in the Morality of Law and Politics. Oxford: Clarendon, 1994, p. 215.

${ }^{56}$ RAZ, Joseph. Ethics in the Public Domain: Essays in the Morality of Law and Politics. Oxford: Clarendon, 1994, p. 218.

${ }^{57} \mathrm{RAZ}$, Joseph. Ethics in the Public Domain: Essays in the Morality of Law and Politics. Oxford: Clarendon, 1994, p. 220.

${ }^{58}$ “The authority of writers, without the authority of the Commonwealth, maketh not their opinions law, be they never so true. That which I have written in this treatise concerning the moral virtues, and of their necessity for the procuring and maintaining peace, though it be evident truth, is not therefore presently law, but because in all Commonwealths in the world it is part of the civil law. For though it be naturally reasonable, yet it is by the sovereign power that it is law" [HOBBES, Thomas. Leviathan. London: Penguin, 1985, Chap. XXVI].

59“'The Sentence he [the judge] giveth, is therefore the Interpretation of the Law of Nature; which Interpretation is Authentique; not because it is his private Sentence; but because he giveth it by Authority of the Soveraign, whereby it becomes the Soveraigns Sentence; which is Law for that time, to the parties pleading [HOBBES, Thomas. Leviathan. London: Penguin, 1985, Chap. XXVI].

${ }_{60 "}$ "Por mais absolutista que a teoria do legalismo positivista hobbesiano seja, ela não absorve a liberdade natural como fonte do direito. Para o teórico político inglês, nenhum homem pode ser obrigado a se matar, a ser proibido de defender a integridade física e de eliminar quem atenta contra a sua vida, a ser forçado a confessar um crime sem garantias de perdão ou a cumprir ordens que impliquem alto risco ou desabonem a sua honra. Hobbes não integra o direito na lei e nem ajusta a lei ao direito, de modo que à liberdade natural dos súditos não corresponde lacuna legal nos comandos do soberano" [HECK, José N. Thomas Hobbes : passado e futuro. Goiânia: EdUFG, 2004, p. 135-6]. 
e veritas: auctoritas, non veritas, facit legem ${ }^{61}$. Schmitt explica, com precisão, o que pode ser extraído do ensinamento da dicção hobbesiana do poder soberano, a saber, a decisão adicionaria algo que não estaria contido no conteúdo da norma. Esse algo seria indiferente ao conteúdo, de tal forma que, se a decisão fosse pensada como um silogismo no qual a norma ocupasse a posição da premissa maior e o fato a posição da premissa menor, na conclusão, ou seja, na decisão, haveria um elemento não contido nas premissas, sendo tal elemento aquele da autoridade, justamente o que determina o conteúdo concreto, bem como sua efetividade, indiferente à justiça do mesmo ${ }^{62}$. Isso desacopla o predicado da força de uma decisão daquele de sua fundamentação, da evidência de sua verdade moral: "a força jurídica de uma decisão é algo distinto do resultado de sua fundamentação" ${ }^{\text {"3 }}$. Tudo o que importa é que se estabeleça a autoridade como aquela que tem competência para decidir, pois, apostrofa ele, "qualquer um poderia remeter-se a um conteúdo correto se não existisse uma instância última. Por conseguinte, o problema é o da competência: a qualidade jurídica do conteúdo de um preceito nem sequer permite levantar esse problema, muito menos resolvê-lo" ${ }^{64}$.

Pode-se concluir da argumentação acima que os princípios morais ou não cumprem a função de motivar, de fazer diferença prática nas razões para agir, como pensa Raz, conforme acima exposto, ou não cumprem a função epistemológica de dizer com clareza o que fazer ${ }^{65}$. Nesse sentido, preceitos jurídicos cumprem a função epistemológica de conhecer o que fazer. Se o preceito não fosse capaz dessa determinação, só restaria a virtude. Porém, o sistema jurídico não sobrevive da virtude, por definição.

Dois exemplos podem ajudar a entender o ponto de vista dos positivistas exclusivistas. O primeiro é aquele do comando constitucional que pró́be penas cruéis, pois a sua determinação depende da noção moral de crueldade, sobre a qual não há consenso ${ }^{66}$. Poder-se-ia perguntar: a pena de morte executada sem dor física alguma, é cruel? Encarcerar alguém por vinte anos, por exemplo, durante toda a sua juventude, dos vinte aos quarenta anos, é cruel? O ponto é que a crueldade só operará, juridicamente, por um ato de determinação da autoridade, e não pela justiça intrínseca do conteúdo específico que decorre dela, haja vista tal conteúdo ser ele mesmo problemático. Assim, nos Estados Unidos a pena de morte não é considerada cruel pela Suprema Corte, ao passo que no Brasil, ela pode ser considerada cruel. Por isso, na verdade, a noção moral posta à base da norma é incapaz de fornecer uma razão para agir ou determinar, sob o ponto de vista epistemológico, o que fazer.

${ }^{61}$ SCHMITT, Carl. Political Theology: Four Chapters on the Concept of Sovereignty. [Trans. by George Schwab: Politische Theologie: Vier Kapitel zur Lehre von der Souveränität]. Cambridge: The MIT Press, 1985 [1922], p. 33. Ver também SCHMITT, Carl. El Leviathan en la teoría del estado de Tomas Hobbes. [Trad. F. J. Conde]. Granada: Comares, 2004, p. 39. Para um maior esclarecimento do conceito de auctoritas ver: AGAMBEN, Giorgio. Estado de exceção. [I. D. Poleti: Stato direitos eccezione]. São Paulo: Boitempo, 2004, cap. 6.

${ }^{62}$ A decisão "agrega um elemento impossível de derivar do conteúdo da mesma, assim como tampouco, ao aplicar-se uma norma positiva geral, do conteúdo desta. Cada decisão jurídica concreta contém um elemento de indiferença com respeito ao conteúdo porque a conclusão jurídica não emana em sua totalidade de suas premissas e o fato de ser necessária a decisão se conserva como elemento determinante autônomo" [SCHMIT, Carl. Political Theology: Four Chapters on the Concept of Sovereignty. [Trans. by George Schwab: Politische Theologie: Vier Kapitel zur Lehre von der Souveränität]. Cambridge: The MIT Press, 1985 [1922], p. 30].

${ }^{63}$ SCHMITT, Carl. Political Theology: Four Chapters on the Concept of Sovereignty. [Trans. by George Schwab: Politische Theologie: Vier Kapitel zur Lehre von der Souveränität]. Cambridge: The MIT Press, 1985 [1922], p. 32.

${ }^{64}$ SCHMITT, Carl. Political Theology: Four Chapters on the Concept of Sovereignty. [Trans. by George Schwab: Politische Theologie: Vier Kapitel zur Lehre von der Souveränität]. Cambridge: The MIT Press, 1985 [1922], p. 33.

${ }^{65}$ HIMMA, Kenneth Einar. Law's Claim of Legimate Authority. In COLEMAN, Jules (Ed.). Hart's Postscript: Essays on the Postscript to the 'Concept of Law'. Oxford University Press, 2001, p. 271-310.

${ }^{66}$ HIMMA, Kenneth Einar. Law's Claim of Legimate Authority. In COLEMAN, Jules (Ed.). Hart's Postscript: Essays on the Postscript to the 'Concept of Law'. Oxford University Press, 2001, p. 275. 
O exemplo seguinte também pode ilustrar o ponto de vista do positivismo exclusivo. Suponha que um cientista diga, em 2010, que a teoria do big bang estará provada se a resolução da equação $\alpha$ for positiva. Significa que o mencionado cientista provou a teoria do big bang? Suponha-se que em 2020 a equação $\alpha$ seja resolvida positivamente. Teria aquele cientista provado a teoria? O ponto é que há algo que precisa ser determinado, mas tal determinação é remetida a um conceito ele próprio indeterminado. A esses argumentos endereçados contra os que conectam o direito à moral, deve-se acrescentar, ainda, uma consideração que Dworkin articula como positivismo político ${ }^{67}$, a saber, a dificuldade de atribuir ao autor das leis, ao legislador, a regra deduzida de um princípio moral, devido a uma derivação indireta que é feita a partir dos princípios. Ou seja, como sustenta Dworkin, o positivismo jurídico porta uma aura de defesa da democracia. Veja-se, nesse sentido, como se expressa Raz: a tese da incorporação "makes the law include standards which are inconsistent with its mediating role, for they were never endorsed by the law-making institutions on whose authority they are supposed to rest"68.

A decisão, portanto, é a questão que se delineia como problema na filosofia do direito de Habermas. Ele pretende discipliná-la no emaranhado dos processos comunicativos. No entanto, os motivos que o levam a aproximar a racionalidade comunicativa e o direito não lhe permitem manter uma simetria estrita com o operar da teoria discursiva na ética discursiva. Se nesta, por um lado, os processos comunicativos vigem plenamente, inclusive dispondo do tempo que for preciso, por outro lado, no direito, eles são interrompidos em um dado momento, de tal forma que, neste momento preciso da interrupção, a formulação schmittiana da decisão é aquela que teima em se furtar aos procedimentos comunicativos. Dito claramente, no direito se imiscui um elemento estranho ao procedimento comunicativo, aquele da autoridade que se une a uma dada interpretação. A pergunta que cabe é se a sua teoria discursiva consegue evitar a objeção de Schmitt, a saber, de que a decisão seria um elemento que não se seguiria do conteúdo da norma.

Feitas essas considerações, pode-se apontar para uma aproximação possível da teoria discursiva do direito de Habermas com a defesa da autoridade operada pelos positivistas jurídicos exclusivistas.

\section{A teoria discursiva do direito de Habermas: a tese da complementaridade}

Considerando-se a exposição acima, torna-se viável vislumbrar uma possibilidade de análise da posição de Habermas, no sentido de melhor compreender algumas consequências de duas teses principais de sua filosofia do direito, quais sejam, a) a tese da neutralidade moral do princípio do discurso, em conjunto com b) a tese da complementaridade entre direito e moral.

A relação do direito com a teoria da ação comunicativa, tal qual ela é apresentada nos primeiros capítulos de FG, visa a dar conta do problema da integração social. Ou seja, a questão que o direito tem que resolver é aquele da integração, frente a um mundo vivido pluralizado, frente à secularização $0^{69}$. Na modernidade, acontece o que Nobre chama de uma pluralidade de eticidades ${ }^{70}$. Tais eticidades plurais podem chegar ao ponto de um conflito violento, como mostraram as guerras religiosas na Europa. Além dessa pluralidade, a própria racionalidade comunicativa porta embutida em si não só um risco de dissenso ${ }^{71}$, mas também

\footnotetext{
${ }^{67}$ DWORKIN, Ronald. Justice in Robes. Cambridge: Harvard University Press, 2006, p. 27.

${ }^{68}$ RAZ, Joseph. Ethics in the Public Domain: Essays in the Morality of Law and Politics. Oxford: Clarendon, 1994, p. 229.

${ }^{69} \mathrm{TrFG} 1$ p. 46 [FG p. 43-44]. Ver a esse respeito ARAUJO, Luiz Bernardo Leite. Religião e Modernidade em Habermas. São Paulo: Loyola, 1996.

${ }^{70}$ NOBRE, Marcos, TERRA, Ricardo (orgs.). Direito e democracia: um guia de leitura de Habermas. São Paulo: Malheiros, 2008, p. 16

${ }^{71} \operatorname{TrFG} 1$ p. 40 [FG p. 37-38].
} 
germes anárquicos ${ }^{72}$, decorrente do próprio modo como ela concebe o resgate de pretensões de validade, a saber, discursivamente.

É nesse sentido que o direito é talhado para resolver esse problema concernente à integração. Ele o resolve porque um de seus elementos é baseado na "faticidade artificial da ameaça de sanções" outras palavras, o direito é capaz de se revestir com a força do fatual, seja no sentido de uma sanção que pode ser imposta (multa), como pena por um ato feito, seja como exclusão da sociedade daquele indivíduo que não cumpre suas determinações (encarceramento, pena de morte), seja ainda mediante os agentes do Estado fazendo o que o indivíduo não faz espontaneamente, como é o caso quando ocorre a expropriação de um bem para pagamento de uma dívida. Dito claramente, o direito tem força, uma força que se determina como tensão entre poder e violência. É nesse sentido que pode ser lida a própria definição de direito que Habermas oferta: "Por 'direito' eu entendo o moderno direito normatizado, que se apresenta com a pretensão à fundamentação sistemática, à interpretação obrigatória e à imposição" Esta definição contém ao menos três elementos essenciais: a fundamentação, a interpretação vinculante e a imposição coercitiva. Ao primeiro elemento Habermas responde com o princípio da democracia. Contudo, ele dedica ao menos dois capítulos de sua obra à interpretação, justamente um dos pontos centrais tratados por Hobbes e, contemporaneamente, parte central da objeção dos positivistas jurídicos exclusivistas, tanto aos positivistas jurídicos inclusivistas, quanto à posição que vincula direito e moral. É justamente este o ponto que está em questão quando Habermas trata da complementaridade do direito em relação à moral no que concerne ao seu aspecto cognitivo.

De fato, Habermas pretende substituir uma concepção de direito que o vê como um caso especial da moral, ou seja, como se fosse uma moral limitada, incompleta, restringida, posição esta que ele imputa a Kant ${ }^{75}$. Isso implica dizer, na concepção da teoria discursiva, que o direito acaba subordinado à moral. Não obstante, essa posição recusada por Habermas, e que ele próprio sustentara na Tanner Lectures, é interessante por ser um tratamento normativo do direito. Ora, essa perspectiva é substituída por uma que ele nomina como "relação sociológica complementar entre moral e direito" ${ }^{\text {". }}$. Se for perguntado ao texto o que seria uma tal relação sociológica, uma resposta que poderia ser encontrada seria aquela de se tratar de uma explicação funcional, quer dizer, não normativa ${ }^{77}$. Portanto, a explicação do papel que o direito cumpre não é normativa, mas funcional, sociológica. Essa terminologia sugere, como hipótese de interpretação, uma proximidade com as posições dos positivistas jurídicos exclusivistas, bem como com o modo como Hobbes e Schmitt conceberam o direito, ou seja, como uma instituição despida de normatividade, mas capaz de decidir.

Essa impressão parece confirmada quando se analisa com detalhe os termos da complementaridade pensada pela teoria discursiva do direito. Segundo Habermas, o direito compensa déficits oriundos da decomposição da eticidade tradicional, portanto, como já alavancado, problemas decorrentes das eticidades plurais. São três exigências aliviadas [entlasten], a saber, cognitivas, motivacionais e organizatórias. Nesse diapasão, deve-se dar especial relevo para a exigência cognitiva, justamente a primeira delas nominada por Habermas. É nesse sentido que já no nível da fundamentação dos princípios ocorre um problema que advém da própria formulação discursiva da moral, a saber, a sua incapacidade de fornecer "um catálogo de

\footnotetext{
${ }^{72}$ TrFG1 p. 11 [FG p. 10].

${ }^{73} \operatorname{TrFG1}$ p. 50 [FG p. 47].

${ }^{74} \mathrm{TrFG1}$ p. 110. "Unter 'Recht' verstehe ich das moderne gesatzte Recht, das mit dem Anspruch auf systematische Begründung sowie verbindliche Interpretation und Durchsetzung auftritt” [FG p. 106].

${ }^{75} \operatorname{TrFG1}$ p. 148 [FG p. 144-5].

${ }^{76} \mathrm{TrFG1}$ p. 148 [FG p. 144-5].

${ }^{77} \operatorname{TrFG} 1$ p.147 [FG p. 143].
} 
deveres". Por seu turno, no nível da aplicação, o problema é aquele da falibilidade das opiniões no conflito das interpretações. Este último é o ponto mais importante, na medida em que se faz necessária uma decisão em um evento de conflito. Neste caso, dentre outras coisas, a norma terá que ser interpretada. É nesse estágio que a autoridade intervém como complemento, por meio do legislativo que formula a norma e, mais importante, por meio do judiciário que resolve o conflito interpretativo de forma definitiva, ou seja, com força de coisa julgada ${ }^{78}$. Anote-se que se trata de resolver um conflito de interpretação de uma norma, portanto, trata-se de decidir por uma interpretação dentre várias, o que o direito faz de forma definitiva no que concerne à determinação da ação. Justamente isso está contido na definição do conceito de direito que Habermas ofertou, a saber, como aquele que fornece uma interpretação obrigatória que é imposta mediante uma sanção artificial. Para uma melhor explicação disso, poder-se-ia fazer referência, mutatis mutandis, à frase do bispo Hoadly, inclusive citada por Hart"9: "Seja quem for que tenha uma autoridade absoluta de interpretar quaisquer leis faladas ou escritas, é ele quem é o legislador verdadeiro para todos os efeitos e propósitos e não a pessoa que primeiro as escreveu ou falou" ${ }^{\text {"80 }}$. Se for o direito aquele que especificará os casos particulares da norma, ou seja, que a interpretará em vista das circunstâncias, então, será ele que determinará o conteúdo do princípio em questão, e não a moral.

Como sugerido acima, uma das objeções centrais do positivismo jurídico à moral é a sua indeterminação cognitiva. Isso vale para Kelsen ${ }^{81}$, $\operatorname{Hart}^{82}$ e mesmo para Weber ${ }^{83}$. Nesse diapasão, o próprio Habermas admite que a racionalidade comunicativa não fornece orientações substantivas para a ação ${ }^{84}$. Certo, a indeterminação pode ser alegada também em relação ao direito, visto ser uma regra formulada linguisticamente e, portanto, como mostra a análise de Hobbes, sujeita à vaguidade. Contudo, o específico do direito é justamente o poder de tornar vinculante a sua interpretação pela autoridade e de impor tal interpretação. Esse recurso é precisamente o que a moral não dispõe. Então, na formulação positivista, a moral não pode ser chamada para resolver uma contenda, porque toda conclusão que ela possa ofertar sempre poderá ser objeto de uma nova contenda, não tendo ela o poder de vincular a ação à sua interpretação, nem muito menos sendo capaz de determinar claramente o que fazer. Quando o direito intervém, ele o faz de forma terminativa da discussão para aquele caso, contudo, não será a verdade do conteúdo da norma que determinará a solução, porque isso sempre estará sob contenda, mas a autoridade imporá uma interpretação. Isso é o que se resume no brocardo auctoritas, non veritas, facit legem. Ora, é justamente o caráter da autoridade que é posta por Habermas como complemento das insuficiências cognitivas da moral.

${ }^{78} \operatorname{TrFG} 1$ p. 151 [FG p. 147].

${ }^{79}$ HART, H. L. A. The Concept of Law. 2. ed., Oxford: Clarendon Press, 1994 [1961], p. 141.

${ }^{80}$ HOADLY, Benjamin. The Nature of the Kingdom or Church of Christ. London: James Knapton, 1717.

${ }^{81}$ Kelsen sustenta a relatividade das morais e dos valores morais [KELSEN, Hans. Teoria pura do direito. [J. B. Machado: Reine Rechtslehre].3. ed., São Paulo: Martins Fontes, 1991, p. 53, 69s], bem como a indeterminação dos princípios de justiça [KELSEN, Hans. Teoria geral do direito e do Estado. [L. C. Borges: General Theory of Law and State]. São Paulo: Martins Fontes, 2000, p. 14-15].

${ }^{82}$ Segundo ele, há discordância com relação ao conjunto das normas que têm status moral, bem como não há concordância quanto ao status epistêmico de tais normas, se são imutáveis ou dependem de atitudes humanas que mudam, ou seja, há teorias filosóficas rivais [HART, H. L. A. The Concept of Law. Oxford: Oxford University Press, 1961, p. 164].

\footnotetext{
${ }^{83}$ No capítulo Economia e direito, Weber constata como o direito natural formal, por exemplo aquele do modelo contratualista, se transformou progressivamente em direito natural substantivo, a partir de determinações sociais e econômicas, como é o caso do socialismo ou das posições regulamentadoras e limitadoras da vontade contratual negocial. Tal é o caso da tese da exploração daquele que se encontra em estado de necessidade, tratado pela lei da usura, a qual proíbe juros elevados, e da nulidade das cláusulas contratuais leoninas. Tais limitações ao formalismo só podem ser feitas, segundo ele, a partir de determinações materiais, ligadas, não ao mundo jurídico, mas ao mundo ético, o qual porta, para Weber, uma certa dose de irracionalidade por remeter sempre a uma moral tradicional [WEBER, Max. Wirtschaft und Gesellschaft. Tübingen: Mohr, s/d, Kap. VII].

84"Ela mesma [a razão comunicativa] não fornece nenhum tipo de indicação concreta para o desempenho de tarefas práticas, pois não é informativa, nem imediatamente prática” [TrFG1 p.21 [FG p. 19]].
} 
Contudo, em tal relação complementar pretendida por Habermas, o papel do direito parece ter sobrepujado aquele da moral. Senão, veja-se. A moral cumpre um papel negativo de veto sobre normas jurídicas que não forem compatíveis com os princípios por ela estabelecidos. Não obstante, pela própria dicção de Habermas, os princípios são indeterminados e devem, portanto, ser complementados pelo direito. Porém, se o direito pode dizer, de forma definitiva e com força de autoridade, o conteúdo dos princípios, não teria ele avocado para si a determinação dos próprios princípios, haja vista estes serem não só indeterminados, mas, fundamentalmente, controversos no seu escopo de aplicação? Assim, no que se distinguiria a sua teoria da maneira como certos positivistas jurídicos entendem a sua própria posição com relação à moral? Ou seja, a possibilidade de resolver definitivamente um conflito só pode ocorrer porque a autoridade empresta coerção a uma dada interpretação, a qual passa a valer, então, não pela sua verdade intrínseca, mas por ter ela emanado da autoridade. É o que ensina Hobbes no cap. XXVI do Leviathan.

Concernente ao positivismo de Habermas, Heck, por exemplo, apostrofa, lapidarmente, que "a ética discursiva encontra-se tout court substituída pela democracia" ${ }^{85}$. Kettner, ao analisar FG em sua totalidade, conclui que a ética discursiva desapareceu do empreendimento desta obra, afirmação que tem clara referência à mudança operada por Habermas no que diz respeito à relação entre moral e direito ${ }^{86}$. Apel sustenta que a neutralidade do princípio do discurso tem conexão com a falta de justificação normativa da forma jurídica ${ }^{87}$. Nesse sentido, parece como se Habermas defendesse um tipo peculiar de positivismo jurídico ${ }^{88}$, talvez, com algumas analogias com um tipo de positivismo também imputado a Kant ${ }^{89}$, ou, de forma mais musculada, acabaria por se posicionar de forma análoga a Kelsen e a Hart ${ }^{90}$.

\section{Conclusão}

A definição de direito do cap. II de FG resolve um problema, cuja solução implica o tipo de função que o positivista jurídico exclusivo imputa ao sistema jurídico e que, segundo Habermas, a moral não tem o condão de cumprir. Ora, Habermas, em um primeiro momento, define o direito de modo tal que ele cumpre a função da interpretação obrigatória e da imposição. Em um segundo momento, ele estabelece uma relação com a moral, contudo, não abandona a sua definição de direito nessa conexão, ao contrário,

${ }^{85}$ HECK, José N. Razão prática: uma questão de palavras? A controvérsia Habermas/Kant sobre moral e direito. Kant e-prints. Campinas: Série 2, v. 1, n.1, 2006, p. 19-30.

${ }^{86} \mathrm{KETTNER}$, Matthias. The Disappearance of Discourse Ethics in Habermas's Between Facts and Norms. IN BAYNES, Kenneth, SCHOMBERG, René von. Essays on Habermas's "Between Facts and Norms”. Albany: SUNY, 2002, p. $201-218$.

${ }^{87}$ Apel conecta fortemente a citação de Habermas com essa tese: APEL, Karl-Otto, OLIVEIRA, Manfredo Araújo de, MOREIRA, Luiz. Com Habermas, contra Habermas: direito, discurso e democracia. São Paulo: Landy, 2004, p. 224. Ver a esse respeito VOLPATO DUTRA, Delamar José. Apel versus Habermas: como dissolver a ética discursiva para salvaguardá-la juridicamente. Kriterion. V. 51, 2010, p. 103-116.

88 "Habermas defends a novel version of legal positivism" [MAHONEY, Jon. Rights without Dignity? Some Critical Reflections on Habermas's Procedural Model of Law and Democracy. Philosophy \& Social Criticism. V. 27, n. 3, 2001, p. 25].

89“"Kant não condiciona a vinculação do direito estatal à exigência de que as leis positivas sejam corretas, boas ou justas” [HECK, José N. Da razão prática ao Kant tardio. Porto Alegre: EDIPUCRS, 2007, p. 88]; WALDRON, Jeremy. Kant's Legal Positivism. Harvard Law Review. N. 109, 1995-1996, p. 1535-1566.

90 "Moreover, a major concern of Between Facts and Norms is to distinguish moral norms from legal norms without subordinating the latter to the former, as is standard practice in natural law approaches up through Dworkin. The similarity here between Habermas's position and that of modern legal positivism - in particular the work of Hans Kelsen and H. L. A. Hart-is notable, complete with their collective insistence that a failure to distinguish clearly between moral questions and questions of legal validity leads to 'confusion' or 'muddled analyses.' And as with the legal positivists, the point of this move is not to insulate law from moral criticism, but to insist on the value, for the purposes of theoretical clarity, of distinguishing between different kinds of validity" [HEDRICK, Todd. Rawls and Habermas: Reason, Pluralism, and the Claims of Political Philosophy. Stanford: Stanford University Press, 2010, p. 86-7]. 
ele parece exigir que o direito complemente a moral em suas deficiências cognitivas. Se for assim, como conciliar a recepção de Dworkin com uma tal posição?

A teoria discursiva do direito de Habermas não só neutraliza moralmente o princípio do discurso, como também introduz o direito de modo a complementar a moral, incluso no sentido cognitivo. E este é justamente o problema. Se os autores de estirpe positivista são, francamente, nãocognitivistas, ou mesmo céticos, o cognitivismo de Habermas restou enfraquecido em razão do viés processual de sua teoria ${ }^{91}$. Ou seja, nela se desenha um não-cognitivismo fraco em relação aos conteúdos ${ }^{92}$. Por outro lado, o que ele reputa como vantagem para a moral, o caráter abstrato das suas proposições como determinação necessária para gerar consenso e tratar matérias de justiça que versam sobre o interesse de todos, implica uma despotencialização de conteúdo, por ele mesmo reconhecida, como já mencionado. Tudo isso, não só rebaixa a moral a um papel correcional negativo em relação ao direito ${ }^{93}$, ou seja, a um conjunto de princípios contra os quais o direito não pode atentar, como imputa ao próprio direito a determinação, a especificação, dos princípios que devem lhe limitar.

O mencionado papel correcional negativo, é verdade, levou alguns intérpretes a verem no empreendimento de FG uma operatividade da ética discursiva maior do que o próprio Habermas admitiu. Regh, por exemplo, identifica no princípio do discurso neutralizado moralmente traços da moralidade que se pretendia ter extirpado, a saber, a unanimidade ${ }^{94}$. Porém, esta aparente prevalência da moral esbarra na tese do caráter complementar que o direito desempenha em relação ao próprio aspecto cognitivo da moral. Com efeito, quem diz os casos particulares de aplicação, diz o conteúdo da norma. Assim, considerando as concessões habermasianas neste ponto concernente aos déficits da moral, em que sentido poderia ele ainda apelar à distinção entre soberania e moral como fontes de justificação do direito? Nesse particular, vale a pena repetir a interpretação de Heck, citada acima: "a ética discursiva encontra-se tout court substituída pela democracia" em FG.

Destarte, o apelo que ele faz ao direito para completar a moral parece até mesmo inverter o que Dworkin sustenta e o que ele mesmo fizera nas Tanner Lectures. Dworkin parece recorrer aos princípios morais para completar o déficit cognitivo do direito. Contudo, como Habermas dessubstancia a moral, ele parece ter escorregado para um cognitivismo fraco com relação aos conteúdos, que tem como consequência um déficit cognitivo, cujo preenchimento recorre ao direito, mais especificamente, ao elemento de autoridade [auctoritas] do direito, à sua decisão. Portanto, parece haver uma incongruência entre aceitar a teoria de Dworkin calcada em princípios e imputar ao direito a função, dentre outras, de preencher o déficit cognitivo da moral. Dworkin gostaria de preencher as lacunas do direito com os princípios morais, ao passo que Habermas parece defender justamente o inverso.

\footnotetext{
${ }^{91}$ Lenoble analisa essa problemática a partir do conceito de "indécidabilité" [LENOBLE, Jacques. Droit et communication: la transformation du droit contemporain. Paris: Cerf, 1994].

${ }^{92}$ Sobre os conceitos de "não-cognitivismo forte", "não-cognitivismo fraco", "cognitivismo fraco" e "cognitivismo forte", ver: VOLPATO DUTRA, Delamar José, OLIVEIRA Jr., Nythamar H. F. de. Moral Cognitivism and Legal Positivism in Habermas's and Kant's Philosophy of Law. Ethic@. V. 16, p. 533-546, 2017.

${ }^{93}$ Ver a esse respeito VOLPATO DUTRA, Delamar José. Apel versus Habermas: como dissolver a ética discursiva para salvaguardála juridicamente [no prelo para sair na KRITERION em 2010], bem como, VOLPATO DUTRA, Delamar José; LOIS, C. C. Modelos de moralização do direito: um estudo a partir de Habermas. Seqüência. V. 55, 2007, p. 233-252.

${ }^{94} \mathrm{REGH}$, William. Against Subordination: Morality, Discourse, and Decision in the Legal Theory of Jürgen Habermas. Cardozo Law Review. V. 17, 1995-1996, p. 1147-62.
} 
Há que se mencionar, por fim, dois pontos referentes a essa discussão tratados por Habermas em momentos distintos, mas que devem ser interpretados de forma conexa. O primeiro ponto, como alhures mencionado, diz respeito à recepção da filosofia do direito de Dworkin. Todavia, em relação a esse ponto, Habermas toma dois cuidados. Um dos cuidados consiste em dar uma natureza jurídica aos princípios morais, interpretando-os como os direitos básicos que ele próprio propõe. Habermas pensa, com isso, poder evitar as conotações naturalistas da proposta de Dworkin pela substituição da noção de valor, ou de uma teoria moral realista, pelo conceito de direitos básicos, os quais implicam uma transformação jurídica da sua estrutura moral, capaz de honrar o sentido deontológico da prioridade do justo sobre concepções de bem ${ }^{95}$. Com essa transformação, Habermas pensa poder detectar como operantes, nos princípios sustentados por Dworkin, padrões equivalentes aos direitos básicos que resultam da aplicação do princípio do discurso sobre a forma jurídica ${ }^{96}$. Com isso, Habermas ensaia uma interpretação de Dworkin próxima à sua posição processual.

Portanto, pode ser vislumbrada já nessas formulações uma tentativa de disciplinar a moral pela forma do direito, o que ele mesmo opera com o seu sistema de direitos básicos de linhagem processual, em continência com os quais ele pretende recepcionar a noção de princípios de Dworkin. Há que se observar, ainda, que o núcleo amoral do direito subjetivo que Habermas põe à base do seu sistema, para fugir a uma determinação moralizadora da gênese dos direitos fundamentais, trabalha com a liberação da responsabilidade comunicativa ${ }^{97}$. De estirpe jurídica, a liberdade não pode mais ordenar o único elemento que poderia indicar uma marca de correção capaz de gravitacionar a decisão, a saber, a própria motivação comunicativa da busca do melhor argumento. Liberada dessa motivação, a qual é exigida como marca de uma liberdade que opera no âmbito moral, mas não no jurídico, como pode agora uma tal liberdade vir a se pôr como complemento daquilo cujo déficit só pode ser explicado, na maior parte das vezes, pelo operar da liberdade fora dos trilhos comunicativos? O outro cuidado consiste em substituir o juiz Hércules por procedimentos discursivos.

O segundo ponto é que ele critica a tese alexyana do caso especial. O modelo discursivo do direito proposto por Habermas não pode ser equiparado ao modelo da ética discursiva. Nem o primado da moral pode levar à conclusão da tese do caso especial arguida por Alexy. Tal tese defende que o discurso jurídico seria um caso especial do discurso prático-moral em geral. Seria um caso especial devido a algumas peculiaridades ínsitas ao discurso jurídico, como a existência de norma positivada, a limitação de tempo para que uma decisão seja tomada e o caráter coativo da mesma. Contudo, segundo Alexy, tal especialidade não descaracterizaria a natureza moral do raciocínio jurídico. Habermas, por seu turno, recusa a tese do caso especial, porque ela sugere uma falsa subordinação do direito à moral ${ }^{98}$.

De modo que Dworkin e Alexy têm que ser lidos complementarmente, pois, se com Dworkin Habermas aceita uma certa moralização do direito, ela não vai ao ponto de o transformar em um caso especial do discurso moral. Ora, o que Habermas parece querer honrar, com isso, é o momento da faticidade artificial do direito, esforçando-se a não mais poder para evitar a subordinação do direito à moral. Só que ele executa tal intento de forma exagerada, ao ponto de pôr o direito como complemento da moral em um aspecto

\footnotetext{
${ }^{95} \operatorname{TrFG} 1253-4$ [FG p. 249].

${ }^{96} \mathrm{TrFG} 1256$ [FG p. 253]

${ }^{97}$ Ver a esse respeito VOLPATO DUTRA, Delamar José. Remarks about Kant and Habermas: the connection between law and morals. In ROHDEN, Valério, TERRA, Ricardo R., ALMEIDA, Guido Antônio de. Recht und Frieden in der Philosophie Kants. Akten des X. Internationalen Kant-Kongresses. Band 5. Berlin, New York: Walter de Greyter, 2008, p. 547-556; GÜNTHER, Klaus. Communicative Freedom, communicative Power, and Jurisgenesis. In ROSENFELD, Michel, ARATO, Andrew [eds.]. Habermas on Law and Democracy: Critical Exchanges. Berkeley: University of California Press, 1998, p. 234-286.
}

${ }^{98}$ TrFG1 291 [FG p. 286]. 
que não poderia fazer, sob pena de tangenciar determinações próprias somente do positivismo jurídico exclusivista.

Não se pode deixar de verificar uma certa inconveniência no registro de que o direito seja concebido como complemento da moral justamente para atenuar a sua indeterminação cognitiva, e que, ao mesmo tempo, a moral tenha que ir em socorro do direito quando ele não consegue resolver questões de aplicação, principalmente nos casos difíceis, ponto este que ele parece admitir a partir da recepção do pensamento de Dworkin. Para Habermas é o direito que vem em socorro da moral e não a moral em socorro do direito. A moralização do direito é recusada, não só por uma divisão de trabalho entre direito e moral, mas porque a moral, dadas as suas exigências, não consegue ofertar uma determinação para a prática, nem sob o ponto de vista epistemológico.

De fato, se a moral pudesse gerar a decisão, então, Habermas não precisaria recorrer a um elemento que parece exógeno à teoria discursiva. Ou seja, pareceria aceitável o alívio da moral no quesito da eficácia motivacional, porque decerto há antropologia bastante para conceber o homem como propenso a se fazer uma exceção à norma moral, mas apelar ao elemento fático do direito para preencher o conteúdo cognitivo de uma norma moral, deixa Habermas em dificuldades para responder à objeção de Schmitt de que o conteúdo, então, despediu-se, porque, como já citado, "qualquer um poderia remeter-se a um conteúdo correto se não existisse uma instância última”, sendo este, em última análise, o ponto preciso do positivismo jurídico de Raz. Ora, Dworkin só pode combater a tese positivista porque pode mobilizar princípios substantivos que ele toma por absolutos, ao passo que a teoria discursiva do direito parece conceder demais ao positivismo jurídico.

O positivismo jurídico sustenta: "depois que esse laço [com a moral] foi rompido, o direito passou a afirmar-se, segundo a interpretação positivista, como a forma que reveste determinadas decisões e competências com a força da obrigatoriedade fática" ${ }^{\prime \prime}$. Por certo, as atenuações no cognitivismo moral da ética discursiva que Habermas parece operar em FG não vão ao ponto da incomensurabilidade defendida por algum autores, como Raz, para quem " $\mathrm{A}$ and $\mathrm{B}$ are incommensurate if it is neither true that one is better than the other nor true that they are of equal value" ${ }^{100}$, ou como Waldron, para quem a objetividade moral seria irrelevante para as decisões jurídicas, já que o realismo moral teria pouco a dizer sobre os desacordos morais ${ }^{101}$. Frente a versões mais fortalecidas de não cognitivismo, Habermas sempre se refugia no possível ganho cognitivista dos procedimentos da ética discursiva ${ }^{102}$. Ainda assim, Habermas pode ser acusado de ser vítima de sua própria definição de positivismo jurídico, tendo em vista os elementos da sua análise do conceito de direito, bem como sua análise do papel complementar que o mesmo cumpre no aspecto cognitivo da moral.

\section{Referências}

AGAMBEN, Giorgio. Estado de exceção. [I. D. Poleti: Stato direitos eccezione]. São Paulo: Boitempo, 2004.

ALEXY, Robert. On Two Juxtapositions: Concept and Nature, Law and Philosophy. Some Comments on Joseph Raz's “Can There Be a Theory of Law?” Ratio Juris. V. 20, N. 2, 2007, p. 162-9.

\footnotetext{
${ }^{99} \mathrm{TrFG} 1117$ [FG p. 113].

${ }^{100} \mathrm{RAZ}$, Joseph. The Morality of Freedom. Oxford: Clarendon Press, 1986, p. 322.

${ }^{101}$ WALDRON, Jeremy. Law and Disagreement. Oxford: Oxford University Press, 1999.

${ }^{102}$ HABERMAS, Jürgen. On Law and Disagreement. Some Comments on "Interpretative Pluralism". Ratio Juris. V. 16, N. 2, 2003, p. 187-94.
} 
ALEXY, Robert. The Argument from Injustice. A Reply to Legal Positivism. [B. L. Paulson and S. L. Paulson: Begriff und Geltung des Rechts]. Oxford: Clarendon Press, 2002.

ALEXY, Robert. The Nature of Legal Philosophy. Ratio Juris. V. 17, n. 2, 2004, p. 156-67.

APEL, Karl-Otto, OLIVEIRA, Manfredo Araújo de, MOREIRA, Luiz. Com Habermas, contra Habermas: direito, discurso e democracia. São Paulo: Landy, 2004.

AQUINO, Tomás. Suma teológica. São Paulo: Loyola, s/d [9 volumes].

ARAUJO, Luiz Bernardo Leite. Religião e Modernidade em Habermas. São Paulo: Loyola, 1996.

ARAUJO, Marcelo de. Hugo Grotius, Contractualism, and Legal Positivism. 2008, p. 2. [http://docs.google.com/ fileview?id=0B6dyNye8hIcAMDhiMTFmZmUtMzVmYy00MzAwLTgxMjktOWRjZGYxYmM4ODI1\&hl=en Acesso em dezembro de 2009]

AUSTIN, John. The Province of Jurisprudence Determined. New York: Noonday, 1954. [1832].

BIX, Brian H. Legal Positivism. In GOLDING, Martin P., A. EDMUNDSON, William [Eds.]. The Blackwell Guide to the Philosophy of Law and Legal Theory. Oxford: Blackwell, 2006.

COELHO, André. O positivismo exclusivo de Andrei Marmor: convenções e interpretação. In TORRANO, Bruno, OMMATI, José Emílio Medauer. O positivismo jurídico no século XXI. Rio de Janeiro: Lumen Juris, 2018, p. 255-282.

COLEMAN, Jules L. Beyond Inclusive Legal Positivism. Ratio Juris. V. 22, No. 3, 2009.

DWORKIN, Ronald. Hart and the Concepts of Law. Harvard Law Review Forum. V. 119, 2006.

DWORKIN, Ronald. Justice in Robes. Cambridge: Harvard University Press, 2006.

DWORKIN, Ronald. Taking Rights Seriously. London: Duckworth, 1977.

DWORKIN, Ronald. The Models of Rules. University of Chicago Law Review. N. 14, 1967.

HABERMAS, Jürgen. Direito e democracia: entre faticidade e validade. [v. I]. [Trad. F. B. Siebeneichler: Faktizität und Geltung: Beiträge zur Diskurstheorie des Rechts und des demokratischen Rechtsstaats]. Rio de Janeiro: Tempo Brasileiro, 1997.

HABERMAS, Jürgen. Direito e democracia: entre faticidade e validade. [v. II]. [Trad. F. B. Siebeneichler: Faktizität und Geltung: Beiträge zur Diskurstheorie des Rechts und des demokratischen Rechtsstaats]. Rio de Janeiro: Tempo Brasileiro, 1997.

HABERMAS, Jürgen. Faktizität und Geltung: Beiträge zur Diskurstheorie des Rechts und des demokratischen Rechtsstaats. 4. Auflage, Frankfurt am Main: Suhrkamp, 1994.

HABERMAS, Jürgen. On Law and Disagreement. Some Comments on "Interpretative Pluralism". Ratio Juris. V. 16, N. 2, 2003, p. 187-94

HART, H. L. A. The Concept of Law. 2. ed., Oxford: Clarendon Press, 1994 [1961]. 
HECK, José N. Da razão prática ao Kant tardio. Porto Alegre: EDIPUCRS, 2007.

HECK, José N. Razão prática: uma questão de palavras? A controvérsia Habermas/Kant sobre moral e direito. Kant e-prints. Campinas: Série 2, v. 1, n.1, 2006, p. 19-30.

HECK, José N. Thomas Hobbes: passado e futuro. Goiânia: EdUFG, 2004.

HEDRICK, Todd. Rawls and Habermas: Reason, Pluralism, and the Claims of Political Philosophy. Stanford: Stanford University Press, 2010.

HIMMA, Kenneth Einar. Law's Claim of Legitimate Authority. In COLEMAN, Jules (Ed.). Hart's Postscript: Essays on the Postscript to the 'Concept of Law'. Oxford University Press, 2001, p. 271-310

HOADLY, Benjamin. The Nature of the Kingdom or Church of Christ. London: James Knapton, 1717.

HOBBES, Thomas. Leviathan. London: Penguin, 1985.

KELSEN, Hans. Teoria geral do direito e do Estado. [L. C. Borges: General Theory of Law and State]. São Paulo: Martins Fontes, 2000.

KETTNER, Matthias. The Disappearance of Discourse Ethics in Habermas's Between Facts and Norms. IN BAYNES, Kenneth, SCHOMBERG, René von. Essays on Habermas's "Between Facts and Norms". Albany: SUNY, 2002, p. 201-218.

KRAMER, Matthew H. Where Law and Morality Meet. Oxford: Oxford University Press, 2004.

KRAMER, Matthew H., GRANT, Claire. Introduction. In KRAMER, Matthew H. et al. (eds.). The Legacy of H. L. A. Hart. Oxford: Oxford University Press, 2008.

LENOBLE, Jacques. Droit et communication: la transformation du droit contemporain. Paris: Cerf, 1994.

MAHONEY, Jon. Rights without Dignity? Some Critical Reflections on Habermas's Procedural Model of Law and Democracy. Philosophy \& Social Criticism. V. 27, n. 3, 2001.

NOBRE, Marcos, TERRA, Ricardo (orgs.). Direito e democracia: um guia de leitura de Habermas. São Paulo: Malheiros, 2008.

RAZ, Joseph. Ethics in the Public Domain. Oxford: Oxford University Press, 1994.

RAZ, Joseph. The Authority of Law. Oxford: Clarendon, 1979.

RAZ, Joseph. The Morality of Freedom. Oxford: Clarendon Press, 1986.

REGH, William. Against Subordination: Morality, Discourse, and Decision in the Legal Theory of Jürgen Habermas. Cardozo Law Review. V. 17, 1995-1996, p. 1147-62.

ROSEN, Allen D. Kant's Theory of Justice. Ithaca: Cornell University Press, 1996.

SAINT AUGUSTIN. De libero arbitrio. [Oeuvres de Saint Augustin; VI. Dialogues Philosophiques ; edição de F. J. Thonnard]. 2. ed., Paris: Desclée, 1952. 
SCHMITT, Carl. El Leviathan en la teoría del estado de Tomas Hobbes. [Trad. F. J. Conde]. Granada: Comares, 2004.

SCHMIT, Carl. Political Theology: Four Chapters on the Concept of Sovereignty. [Trans. by George Schwab: Politische Theologie: Vier Kapitel zur Lehre von der Souveränität]. Cambridge: The MIT Press, 1985 [1922].

SHAPIRO, Scott. Law, Morality, and the Guidance of Conduct. Legal Theory. V. 6, 2000, p. 127-170.

VOLPATO DUTRA, Delamar José, LOIS, C. C. Modelos de moralização do direito: um estudo a partir de Habermas. Seqüência. V. 55, 2007, p. 233-252.

VOLPATO DUTRA, Delamar José, OLIVEIRA Jr., Nythamar H. F. de. Moral Cognitivism and Legal Positivism in Habermas's and Kant's Philosophy of Law. Ethic@. V. 16, p. 533-546, 2017.

VOLPATO DUTRA, Delamar José. Apel versus Habermas: como dissolver a ética discursiva para salvaguardá-la juridicamente. Kriterion. V. 51, 2010, p. 103-116.

VOLPATO DUTRA, Delamar José. Manual de Filosofia do Direito. Caxias do Sul: Educs, 2008.

VOLPATO DUTRA, Delamar José. Remarks about Kant and Habermas: the connection between law and morals. In ROHDEN, Valério, TERRA, Ricardo R., ALMEIDA, Guido Antônio de. Recht und Frieden in der Philosophie Kants.Akten des X. Internationalen Kant-Kongresses. Band 5. Berlin, New York: Walter de Greyter, 2008, p. 547-556.

WALDRON, Jeremy. Kant's Legal Positivism. Harvard Law Review. N. 109, 1995-1996, p. 1535-1566.

WALDRON, Jeremy. Law and Disagreement. Oxford: Oxford University Press, 1999

WALUCHOW, W J. Legality, Morality, and the Guiding Function of Law. In KRAMER, Matthew H. et al (eds.). The Legacy of H. L. A. Hart. Oxford: Oxford University Press, 2008.

WEBER, Max. Wirtschaft und Gesellschaft. Tübingen: Mohr, s/d. 
